\title{
A Report on GIS Based Analysis of Landslides in Myagdi District
}

\author{
Sumit Thapa \\ Disaster Risk Management Program, Department of Civil Engineering, \\ Pulchowk Campus, Institute of Engineering, Tribhuvan University, Nepal \\ Corresponding Author: sumitsaya09egmail.com
}

Received: 2020-08-25

Revised: 2021-02-09

Accepted: 2021-02-19

\begin{abstract}
:
Lanslide have become a routine event during monsoon in Nepal which accompanies a huge social, physical and economical loss. As the number of landslide event is in increasing order each year but their proper study is still limited, this assessment is an example of simple step in landslide study. Also, the developmental activities disturb the topology and hence increase or bring new form of landslide in the region. This report is mainly a preliminary study of existing landslide in Myagdi district which is generally carried out using QGIS software and remote sensing data available from http: / / earthexplorer.usgs.gov and recent Google satellite image. From the analysis carried out by using the inbuilt features in QGIS, relationship between various terrain, hydrological and anthropogenic parameters with landslide was driven. Based on this approach a simple precautionary measures in development activities, disaster preparedness and mitigation activities can be carried out.
\end{abstract}

\section{Introduction}

Nepal lies in the South Asian region between China and India. It has a unique landscape which differs with the rise in altitude. So, from plain agricultural land in the southern belt to the high Himalayas in the northern belt, makes Nepal geology different. As the Himalayas were formed 50 million years ago due to the collision of the Indian Plate and Eurasian Plate, the process is continuous and is responsible for different natural disasters[1].

As you look at the hilly and mountainous region of the country, due to geologically young and tectonically active landscapes, this region is highly susceptible to landslide, earthquake, erosion, flood, etc. Every year during monsoon season these catastrophes mark their presence with devastating outcomes resulting in huge human, material, economic and environmental losses.

Varnes [2] has classified landslides based on the type of material and type of movement. Landslide is simply the downward movement of earth material due to external forces under the direction of gravity. A landslide can be natural or human-induced. In the case of Nepal, both types of landslides are found. As mentioned earlier, the landslides are mostly active in the rainy season, most of the landslides are rainfall triggered landslides. About eighty percentage of the landslides in Nepal are shallow type, which moves very fast and are of destructive nature. Generally intense rainfall for short duration is responsible for shallow landslides. As an impact of climate change, there is an increase in the number of short intense rainfall. So, there is an increase in number of disasters related to it.

The parameters like slope, aspect, rainfall characteristics, soil characteristics and landscape influence the type and coverage area of landslides. Landslide is affected by various factors which can be time-invariant or dynamic in nature. The surface and the subsurface geomorphological characteristics of the earth differ spatially. Also, the climatological, hydrographical and environmental conditions may differ from time to time. So, even if the instability factor leading to slope failure are identified, its complex interactions is a subject of discussion if we consider a large region [3]. All methods proposed and tested to evaluate landslide hazard fall into different categories; direct geomorphological mapping, analysis of landslide inventories, heuristic or index-based models, functional or statistical models, physical and geotechnical models. As landslide varies in scale from local to regional, its study is very complicated [3]. 
For this study we are using Geographic Information System (GIS) to map the landslides in Myagdi district and work out its relationship with various parameters. So, GIS approach is simply a statistical approach which considers multiple variables for its study. It is simply a preliminary investigation carried out based on the satellite image, different relevant data and extensive use of inbuilt tools in QGIS.

\subsection{General Information of the Study Site (Myagdi District)}

Myagdi District, a part of Gandaki Province, is one of the seventy-seven districts of Nepal with the coverage area of $2297 \mathrm{~km} 2$.The district has one municipality and five rural municipality. The Dhorpatan Hunting Reserve also lies in this region. Beni Municipality is the district headquarter.

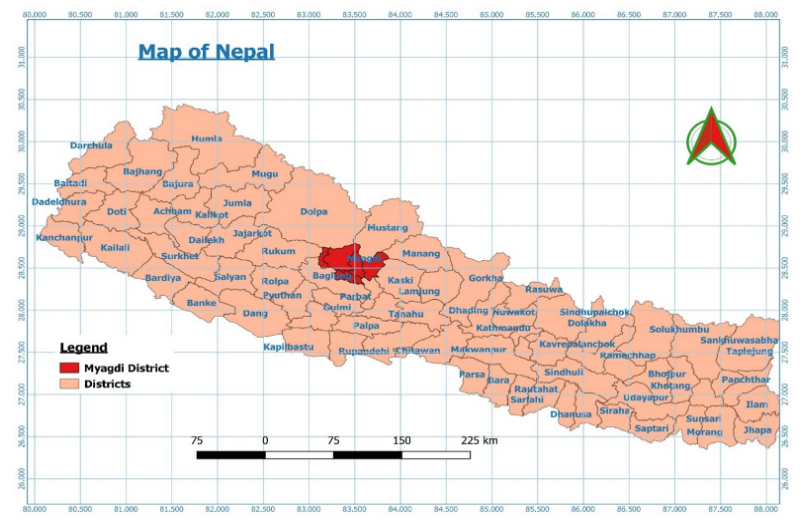

Figure 1: District Location (Source: Extraction from QGIS)

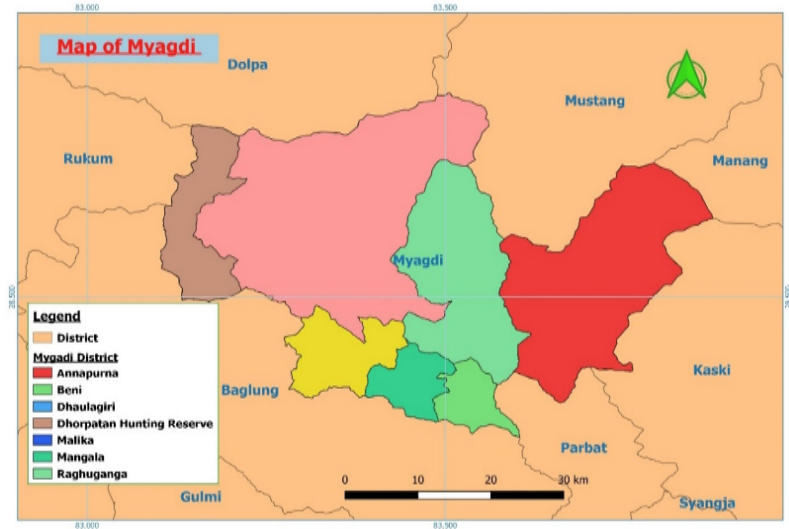

Figure 2: Administrative Division of Myagdi (Source: Extraction from QGIS)

The general information regarding different administrative unit of Myagdi district is listed in Table 1.

Table 1: General Demographic Information (Source-Census 2011)

\begin{tabular}{|l|c|c|}
\hline Administrative Unit & Area $\mathbf{( k m}^{\mathbf{2}}$ ) & Population \\
\hline Beni Municipality & 55.77 & 28,511 \\
\hline Annapurna Rural Municipality & 556.41 & 13,315 \\
\hline Dhaulagiri Rural Municipality & 1037 & 14,014 \\
\hline Mangala Rural Municipality & 89 & 16,286 \\
\hline Malika Rural Municipality & 147 & 19,458 \\
\hline Raghuganga Rural Municipality & 379 & 15,753 \\
\hline
\end{tabular}

\subsection{Landslide situation}

Each year Nepal is badly hit by landslide mainly in hilly region during monsoon season creating a havoc situation. Monsoon induced disasters are common in Nepal owing to country's mountainous topography and big rivers dissecting the landscape as they flow from the mountains to the plains in Terai. Since the beginning of monsoon, the number of floods and landslides highly affect the people living in the vulnerable region. Each year there is a rising tread in the number of landslides due to natural as well as anthropogenic causes. The explosion of informal road construction without proper geotechnical and scientific investigation have destabilize the slopes during monsoon season. As a result of this reckless development the risk and the rate of landslide is increasing in the hilly terrain. According to National Disaster Risk Reduction and Management Authority (NDRRMA) reports as of 31 July, 164 people have lost their lives due to landslides and floods, and many more are missing. The report also shows that within 23 days of active monsoon, a total of 256 water induced disaster took place in Nepal[4].

This year alone 700 people form 50 household have been displaced and 27 people have lost their life due to landslide in various regions of Myagdi district. Around 896 people from Beni Municipality and Dhaulagiri, Malika and Raghu Ganga rural municipalities have been transferred to safer locations. So the study of landslide and mitigation and preparedness activities is still not convincing. A detailed study and effective mitigation and preparedness plan is immediately needed to overcome the challenges of landslide.

\section{Objectives of Study}

The main purpose of this study is the Assessment of Landslides in Myagdi District. The objective of the 
study can be highlighted as:

- Identification and Mapping of Landslides in the district

- Analyze the relationship of Landslides with various topographical and hydrological characteristics and also analyze the influence of human activities

\section{Methodology}

For the following project Landslide mapping and identification was basically done by using the spatial data and using different features of QGIS to analyze the causes and extent of landslide in Myagdi District. At first $30 \mathrm{~m} \times 30 \mathrm{~m}$ resolution Digital Elevation Data (ASTER DEM) was downloaded from USGS website[5]. The data was then used accordingly to conduct different analysis (Terrain and Hydrological) and other relevant tasks in QGIS. Google Earth Software was used to identify the landslides in the area of our interest. So, the Google Satellite image was our prominent source of information to meet our objective. Recent Google Satellite image was used. Terrain analysis was done in order to analyze the relation between landslides and different parameters such as slope, aspect, profile and elevation. Similarly, hydrological analysis was done to extract channel network and delineate watershed. By doing so we can create river network, drainage basins, flow direction, flow accumulation and Strahler order. So, generally a base for analyzing the relationship with landslides and outcomes of hydrological analysis was then looked up carefully. Also, Vector Analysis tools (distance, buffer, and centroid) were used to find more information regarding the relationship of different layers (roads, rivers, drainage basins) with landslides.

\section{Results and Discussion}

Various tools in QGIS have been used to study the existing landslide in order to find its relationship with different terrain and hydrological parameters. The results of terrain and hydrological analysis is elaborated in following subsections:

\subsection{Landslide Inventory}

Landslides were identified by introducing new layer in QGIS and identifying the landslide based on the Google satellite images. Apart from the natural landslide there were few which were human driven, as a result of reckless rural road development. The Landslide No. 33 covers a huge area of $585085.04 \mathrm{~m}^{2}$ and it lies in Dhaulagiri Rural Municipality. In Myagdi district total 71 landslides were identified and based on the area covered by landslide, Raghuganga rural municipality is highly affected followed by Dhaulagiri and so on.

The ranking of the administrative unit based on the landslide coverage area is shown in the Table 2.

Table 2: Landslide Distribution in Myagdi (SourceExtraction from QGIS)

\begin{tabular}{|l|c|c|c|}
\hline Administrative Unit & $\begin{array}{c}\text { Number } \\
\text { of } \\
\text { Landslides }\end{array}$ & Rank & $\begin{array}{c}\text { Area } \\
\text { (Sq. km) }\end{array}$ \\
\hline Beni Municipality & 4 & 5 & 0.278 \\
\hline Raghuganga Rural Municipality & 32 & 1 & 1.314 \\
\hline Malika Rural Municipality & 8 & 3 & 0.558 \\
\hline Annapurna Rural Municipality & 8 & 4 & 0.197 \\
\hline Mangala Rural Municipality & 7 & 6 & 0.062 \\
\hline Dhaulagiri Rural Municipality & 12 & 2 & 1.187 \\
\hline Total & $\mathbf{7 1}$ & & $\mathbf{3 . 5 9 6}$ \\
\hline
\end{tabular}

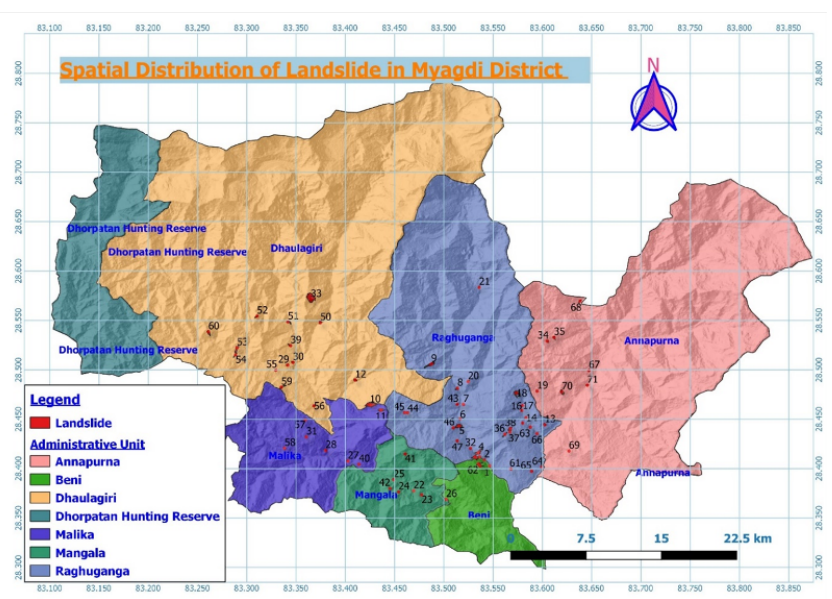

Figure 3: Spatial Distribution of Landslide (Source: Extraction from QGIS)

\subsection{Terrain Analysis}

Terrain analysis includes the use of a (Digital Elevation Model) DEM to model the landscape. It helps to describe, analyze and interpret any topographically related features. Here generally the primary attributes (Slope, Aspect, Profile Curvature, Tangential Curvature, and Hill Shade) of terrain analysis are calculated directly from elevation data[6]. So, a DEM file after attribute calculation gives different terrain attributes. So at first an ASTER GTM (DEM) data was downloaded (Source: earthexplore.usgs.gov) and work was carried 
out on it. Also, this elevation data was used to distinguish the landscape of Myagdi district into different regions based on elevation. (Refer: Table 3). From the figure below we can notice that landslide prone region in hilly region like Myagdi, lies in upper climate zones. The result may be due to soil characteristics, rainfall characteristics, and other phenomenon.

Table 3: Topology of Myagdi (Source: Wikipedia)

\begin{tabular}{|l|c|c|}
\hline Climate Zone & Elevation Range & \% of Area \\
\hline Upper Tropical & $300-1000 \mathrm{~m}$ & 0.1 \\
\hline Subtropical & $1000-2000 \mathrm{~m}$ & 17.5 \\
\hline Temperate & $2000-3000 \mathrm{~m}$ & 28 \\
\hline Subalpine & $3000-4000 \mathrm{~m}$ & 21.1 \\
\hline Alpine & $4000-5000 \mathrm{~m}$ & 17.8 \\
\hline Nival & above $5000 \mathrm{~m}$ & 13.9 \\
\hline Trans-Himalayan & $3000-6400 \mathrm{~m}$ & 1.6 \\
\hline
\end{tabular}

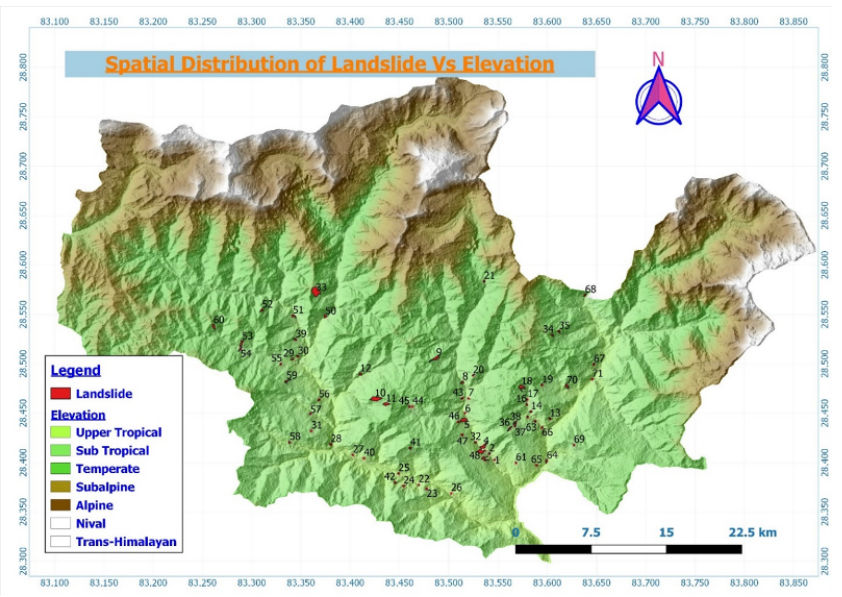

Figure 4: Spatial Distribution of landslide Vs Elevation (Climate Zones)

(Source: Extraction from QGIS)

\subsubsection{HILLSHADE}

Hill shade is one of Raster Analysis function which is used to output the raster with a nice shaded relief effect. Relief refers to the highest and lowest elevation points in an area. Mountains and ridges are typically the highest elevation points, while valleys and other low-lying areas are the lowest. We can specify the azimuth and altitude of the light source, a vertical exaggeration factor and a scaling factor to account for the difference between the horizontal and vertical units. Here we have taken azimuth of light 315 degree and altitude of light as 45 degree. Similarly, vertical exaggeration factor and Z- factor (ratio of vertical and horizontal units) were taken as 1. Generally, for hills the distribution of rainfall is affected on the orientation (leeward and windward). Windward side receive more rainfall than leeward side and is rich in vegetation as compared to the later one. Also, the profile, soil characteristics, rainfall characteristics differs from region to region. These features definitely, influence the spatial distribution of landslide in the region

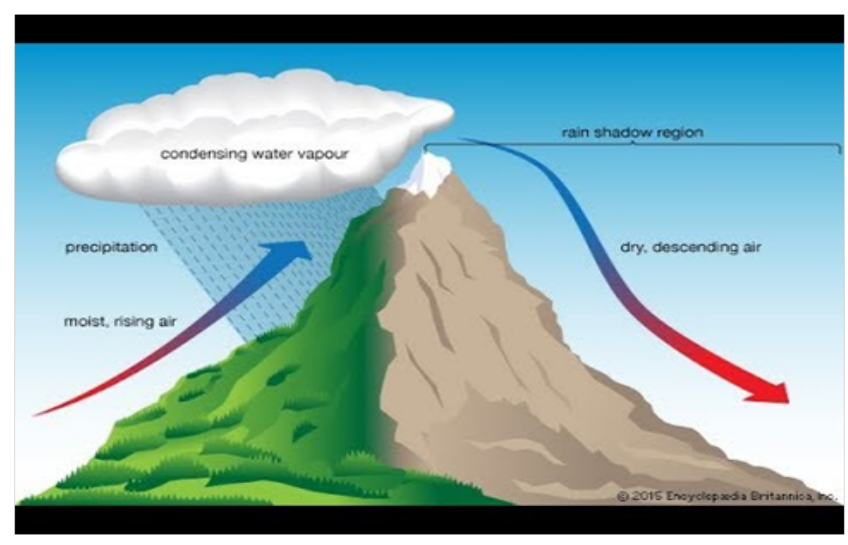

Figure 5: Leeward Side and Windward side of a hill (Source: cimioutdoored.org)

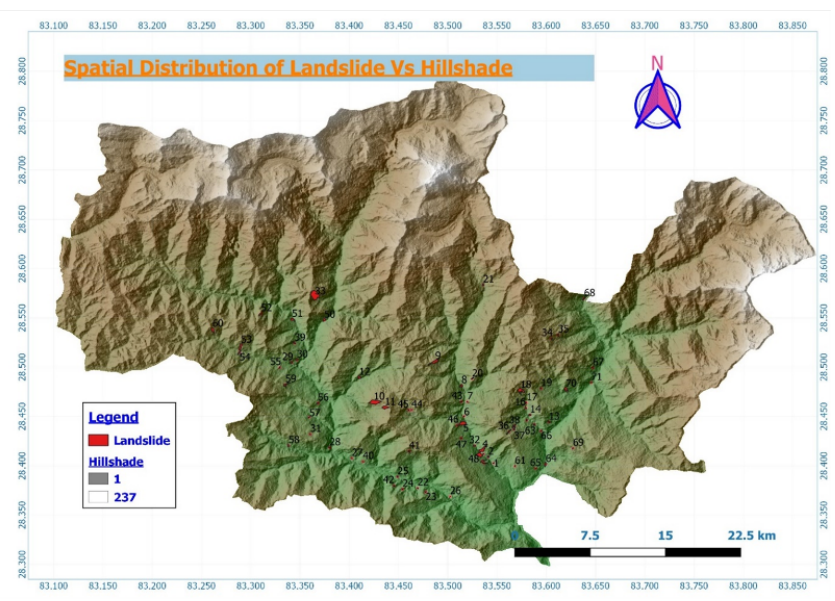

Figure 6: Spatial Distribution of Landslide vs Hill Shade (Source: Extraction from QGIS)

\subsubsection{Slope}

Slope is one of the prominent primary attribute of terrain analysis. It basically shows how steep the hill is. Slope analysis quantifies the maximum rate of change in value from one cell to its neighbors. Slope has direct correlation with water as water always flow downhill. So, it generally shows which way the water is moving with aspect and describes overland and subsurface flow velocity and runoff rate. Among the 71 identified 
landslides, the spatial distribution of landslide based on slope can be summarized as shown in Table 4 .

Table 4: Slope Vs Landslide (Source: Extraction from QGIS)

\begin{tabular}{|c|l|c|}
\hline $\begin{array}{c}\text { Slope } \\
\text { in } \\
\text { Degree }\end{array}$ & Landslide_id & $\begin{array}{c}\text { Number } \\
\text { of } \\
\text { landslide(s) }\end{array}$ \\
\hline $0-15$ & $25,63,64$ & 3 \\
\hline $15-30$ & $\begin{array}{l}1,4,5,6,8,14,15,17,19,21, \\
24,31,32,36,38,39,44,45,46, \\
49,51,53,54,55,57,58,61,62, \\
66,68\end{array}$ & 30 \\
\hline $30-45$ & $\begin{array}{l}3,12,13,20,22,23,26,27,28, \\
37,40,42,43,48,50,56,60,\end{array}$ & 19 \\
\hline $45-60$ & $\begin{array}{l}2,7,9,10,11,16,18,29,30, \\
33,34,35,47,52,59,69,70,71\end{array}$ & 18 \\
\hline $60-75$ & 41 & 1 \\
\hline $75-90$ & & \\
\hline
\end{tabular}

So basically, landslides are higher in number for mild slope as compared to high and low slope values.

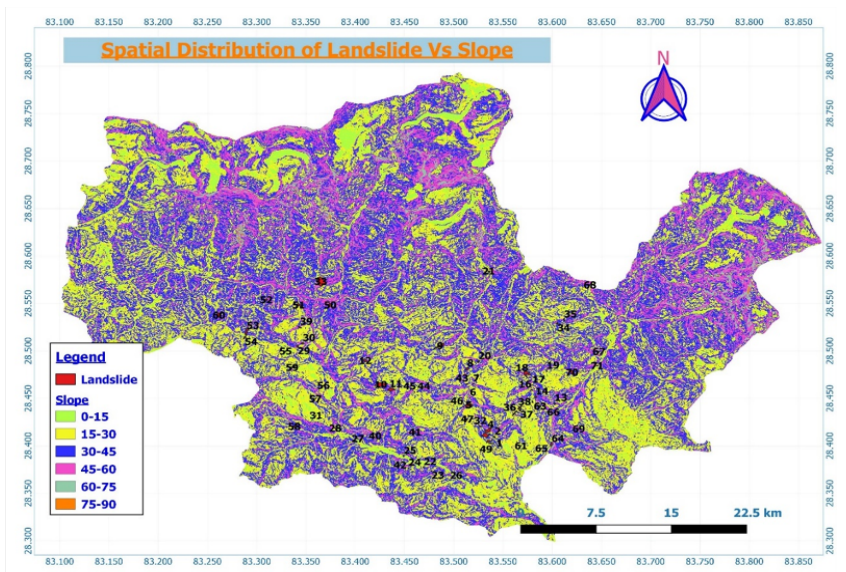

Figure 7: Spatial Distribution of Slope Vs Landslide

\subsubsection{Aspect}

Aspect defines the cardinal direction $\left(0-360^{\circ}\right)$ a surface is facing. It shows which way the landscape is facing. So, Aspect defines the direction of flow. Among the 71 identified landslides, the spatial distribution of landslide based on aspect can be summarized as:
Table 5: Aspect Vs Landslide (Source: Extraction from QGIS)

\begin{tabular}{|c|c|l|c|}
\hline Aspect & Interval & Landslide id & $\begin{array}{c}\text { Number } \\
\text { of } \\
\text { landslides }\end{array}$ \\
\hline $\mathrm{N}$ & $0-22.5$ & & \\
\hline $\mathrm{NE}$ & $22.5-67.5$ & $\begin{array}{l}23,31,36,37,38,48, \\
51,54,57,62,63,64, \\
66\end{array}$ & 13 \\
\hline $\mathrm{E}$ & $67.5-112.5$ & $\begin{array}{l}5,8,15,19,32,49, \\
55,69,70,71\end{array}$ & 10 \\
\hline SE & $112.5-157.5$ & $\begin{array}{l}9,16,17,18,21,24, \\
26,28,33,35,39,42, \\
43,46,47,50,52,56, \\
59,60,67,68\end{array}$ & 22 \\
\hline S & $157.5-202.5$ & $\begin{array}{l}10,12,13,25,29,30, \\
34,40,41,45,61,65\end{array}$ & 12 \\
\hline SW & $202.5-247.5$ & $\begin{array}{l}2,3,4,6,11,14,20, \\
27,44,53,58\end{array}$ & 11 \\
\hline W & $247.5-292.5$ & $1,7,22$ & 3 \\
\hline NW & $292.5-337.5$ & & \\
\hline N & $337.5-360$ & & \\
\hline
\end{tabular}

As we can see that most of the landslides is facing from North East to South West (22.5-247.5 $)$ in Myagdi. It may be one of the factors influencing landside in this region.

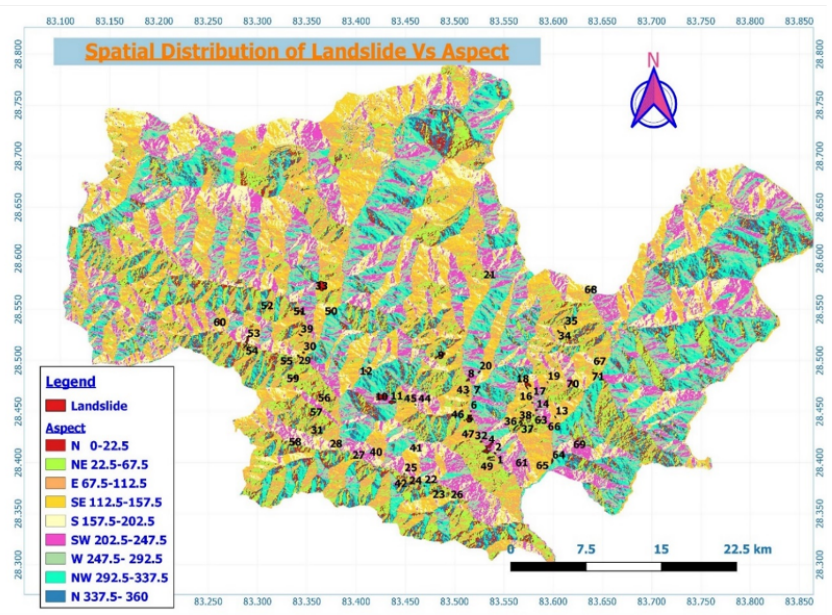

Figure 8: Spatial Distribution of Landslide Vs Aspect

All the result can be summarized as shown in Table 6 . 
Table 6: Terrain Analysis Summary

\begin{tabular}{|c|c|c|c|c|c|c|}
\hline Landslide_id & Latitude & Longitude & Area & Location & Slope & Aspect \\
\hline 1 & 28.40268 & 83.54637 & 4538.79 & Beni & $15-30$ & W \\
\hline 2 & 28.40889 & 83.54103 & 18848.63 & Raghuganga & $45-60$ & SW \\
\hline 3 & 28.41189 & 83.53635 & 6072.5 & Raghuganga & $30-45$ & SW \\
\hline 4 & 28.41608 & 83.53519 & 187698.5 & Raghuganga & $15-30$ & SW \\
\hline 5 & 28.44319 & 83.51552 & 202457.4 & Raghuganga & $15-30$ & $\mathrm{E}$ \\
\hline 6 & 28.45036 & 83.51649 & 5627.88 & Raghuganga & $15-30$ & SW \\
\hline 7 & 28.46502 & 83.51976 & 5536.71 & Raghuganga & $45-60$ & $\mathrm{~W}$ \\
\hline 8 & 28.48134 & 83.51388 & 61502.42 & Raghuganga & $15-30$ & $\mathrm{E}$ \\
\hline 9 & 28.50583 & 83.48726 & 177808.4 & Raghuganga & $45-60$ & SE \\
\hline 10 & 28.46459 & 83.42486 & 359881.7 & Malika & $45-60$ & $\mathrm{~S}$ \\
\hline 11 & 28.45927 & 83.43598 & 147040.6 & Malika & $45-60$ & SW \\
\hline 12 & 28.48968 & 83.41003 & 56175.63 & Raghuganga & $30-45$ & $\mathrm{~S}$ \\
\hline 13 & 28.44432 & 83.60244 & 19205.21 & Raghuganga & $30-45$ & S \\
\hline 14 & 28.45158 & 83.58341 & 30873.83 & Raghuganga & $15-30$ & SW \\
\hline 15 & 28.44609 & 83.57999 & 11158.3 & Raghuganga & $15-30$ & $\mathrm{E}$ \\
\hline 16 & 28.4589 & 83.57915 & 6644.65 & Raghuganga & $45-60$ & SE \\
\hline 17 & 28.46391 & 83.57986 & 1612.84 & Raghuganga & $15-30$ & SE \\
\hline 18 & 28.47656 & 83.57359 & 189000.7 & Raghuganga & $45-60$ & SE \\
\hline 19 & 28.47844 & 83.59466 & 5521.78 & Annapurna & $15-30$ & $\mathrm{E}$ \\
\hline 20 & 28.48806 & 83.52464 & 22914.33 & Raghuganga & $30-45$ & SW \\
\hline 21 & 28.58344 & 83.53584 & 23844.61 & Raghuganga & $15-30$ & SE \\
\hline 22 & 28.37752 & 83.46935 & 8663.7 & Mangala & $30-45$ & $\mathrm{~W}$ \\
\hline 23 & 28.37346 & 83.47751 & 5612.09 & Mangala & $30-45$ & $\mathrm{NE}$ \\
\hline 24 & 28.37632 & 83.45405 & 3058.82 & Mangala & $15-30$ & SE \\
\hline 25 & 28.38881 & 83.449 & 9032.22 & Mangala & $0-15$ & $\mathrm{~S}$ \\
\hline 26 & 28.36889 & 83.50234 & 1743.27 & Mangala & $30-45$ & SE \\
\hline 27 & 28.40762 & 83.40263 & 3258 & Malika & $30-45$ & SW \\
\hline 28 & 28.41836 & 83.38002 & 9261.29 & Malika & $30-45$ & SE \\
\hline 29 & 28.50472 & 83.34151 & 28554.49 & Dhaulagiri & $45-60$ & $\mathrm{~S}$ \\
\hline 30 & 28.50744 & 83.34686 & 34283.56 & Dhaulagiri & $45-60$ & $\mathrm{~S}$ \\
\hline 31 & 28.43203 & 83.36039 & 487.85 & Malika & $15-30$ & $\mathrm{NE}$ \\
\hline 32 & 28.42052 & 83.5271 & 26366.56 & Raghuganga & $15-30$ & $\mathrm{E}$ \\
\hline 33 & 28.57129 & 83.36493 & 585085 & Dhaulagiri & $45-60$ & SE \\
\hline 34 & 28.52902 & 83.60495 & 23002.22 & Annapurna & $45-60$ & $\mathrm{~S}$ \\
\hline 35 & 28.53283 & 83.61185 & 18610.55 & Annapurna & $45-60$ & SE \\
\hline 36 & 28.43478 & 83.56203 & 54558.59 & Raghuganga & $15-30$ & $\mathrm{NE}$ \\
\hline 37 & 28.43705 & 83.56698 & 27282.17 & Raghuganga & $30-45$ & $\mathrm{NE}$ \\
\hline 38 & 28.4406 & 83.56759 & 49809.95 & Raghuganga & $15-30$ & $\mathrm{NE}$ \\
\hline 39 & 28.52445 & 83.3444 & 31039.5 & Dhaulagiri & $15-30$ & SE \\
\hline 40 & 28.40431 & 83.41381 & 1858.63 & Malika & $30-45$ & $\mathrm{~S}$ \\
\hline 41 & 28.41479 & 83.46073 & 20552.31 & Mangala & $60-75$ & $\mathrm{~S}$ \\
\hline 42 & 28.37987 & 83.44543 & 13288.66 & Mangala & $30-45$ & SE \\
\hline 43 & 28.46513 & 83.5136 & 9327.59 & Raghuganga & $30-45$ & SE \\
\hline 44 & 28.45658 & 83.46319 & 1700.5 & Raghuganga & $15-30$ & SW \\
\hline 45 & 28.45665 & 83.46019 & 6295.74 & Raghuganga & $15-30$ & $\mathrm{~S}$ \\
\hline 46 & 28.4413 & 83.50954 & 4113.57 & Raghuganga & $15-30$ & SE \\
\hline 47 & 28.42808 & 83.51358 & 5169.53 & Raghuganga & $45-60$ & SE \\
\hline 48 & 28.41185 & 83.53171 & 190722 & Beni & $30-45$ & $\mathrm{NE}$ \\
\hline 49 & 28.40262 & 83.5368 & 19873.59 & Beni & $15-30$ & $\mathrm{E}$ \\
\hline 50 & 28.54763 & 83.37458 & 64187.1 & Dhaulagiri & $30-45$ & SE \\
\hline 51 & 28.54858 & 83.34165 & 75454.51 & Dhaulagiri & $15-30$ & $\mathrm{NE}$ \\
\hline 52 & 28.55435 & 83.31033 & 36551.75 & Dhaulagiri & $45-60$ & SE \\
\hline 53 & 28.52227 & 83.29008 & 135266.9 & Dhaulagiri & $15-30$ & SW \\
\hline 54 & 28.51508 & 83.28856 & 33935.7 & Dhaulagiri & $15-30$ & $\mathrm{NE}$ \\
\hline 55 & 28.49971 & 83.32941 & 8616.6 & Dhaulagiri & $15-30$ & E \\
\hline 56 & 28.46358 & 83.36812 & 10466.57 & Raghuganga & $30-45$ & SE \\
\hline 57 & 28.44935 & 83.35947 & 9775.81 & Malika & $15-30$ & $\mathrm{NE}$ \\
\hline 58 & 28.42061 & 83.33838 & 26757.45 & Malika & $15-30$ & SW \\
\hline 59 & 28.48243 & 83.33503 & 54610.19 & Dhaulagiri & $45-60$ & SE \\
\hline 60 & 28.53855 & 83.26102 & 99498.92 & Dhaulagiri & $30-45$ & SE \\
\hline 61 & 28.39967 & 83.56806 & 6085.32 & Raghuganga & $15-30$ & $\mathrm{~S}$ \\
\hline 62 & 28.40487 & 83.53502 & 62889.82 & Beni & $15-30$ & $\mathrm{NE}$ \\
\hline 63 & 28.44202 & 83.5878 & 14005.53 & Raghuganga & $0-15$ & $\mathrm{NE}$ \\
\hline 64 & 28.4015 & 83.5993 & 62794.96 & Raghuganga & $0-15$ & $\mathrm{NE}$ \\
\hline 65 & 28.39734 & 83.58903 & 4840.91 & Raghuganga & $30-45$ & $\mathrm{~S}$ \\
\hline 66 & 28.43541 & 83.5945 & 4290.54 & Raghuganga & $15-30$ & $\mathrm{NE}$ \\
\hline 67 & 28.49935 & 83.64717 & 7411.49 & Annapurna & $30-45$ & SE \\
\hline 68 & 28.56947 & 83.6384 & 26843.65 & Annapurna & $15-30$ & SE \\
\hline 69 & 28.4178 & 83.62695 & 9585.19 & Annapurna & $45-60$ & $\mathrm{~S}$ \\
\hline 70 & 28.4777 & 83.61961 & 99712.88 & Annapurna & $45-60$ & $\mathrm{~S}$ \\
\hline 71 & 28.48438 & 83.64556 & 6115.29 & Annapurna & $45-60$ & $\mathrm{~S}$ \\
\hline
\end{tabular}

\subsubsection{Profile Curvature and Tangential Curvature}

Profile Curvature is parallel to the direction of maximum slope. It affects the acceleration and deceleration of flow across the surface and therefore, influences the erosion and deposition. A negative value indicates upwardly convex surface at that cell, positive value indicated upwardly concave and zero value indicates that the surface is linear at that cell. Similarly, Tangential Curvature is perpendicular to the direction of maximum slope. It influences the convergence and divergence of flow. A negative value indicates sideward convex surface at that cell, positive value indicated sideward concave and zero value indicates that the surface is linear at that cell. So, both of this terrain attributes help us understand the topology.

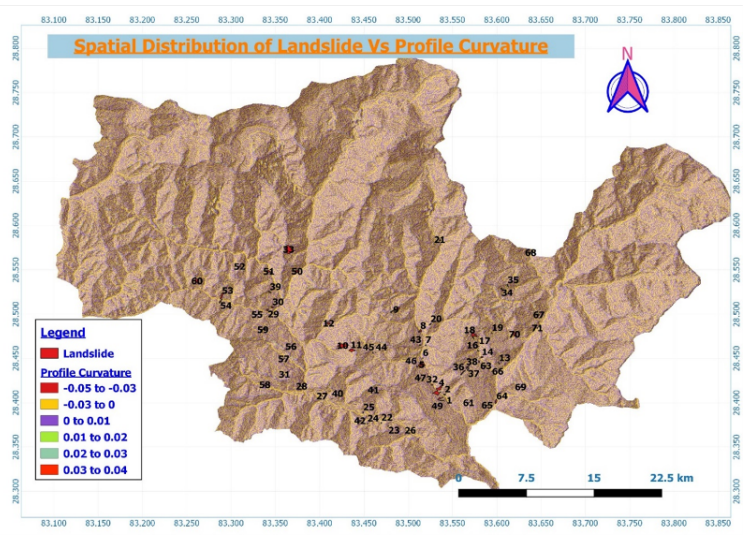

Figure 9: Spatial Distribution of landslide Vs Profile Curvature (Source: Extraction from QGIS)

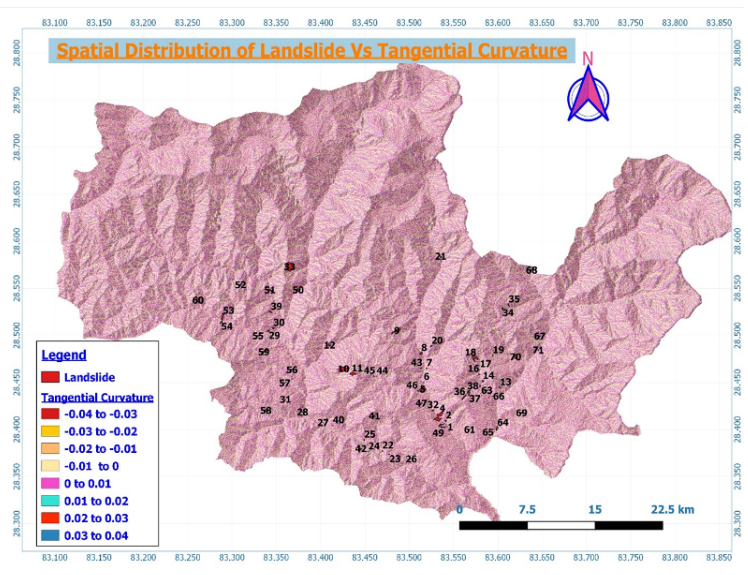

Figure 10: Spatial Distribution of Landslide Vs Tangential Curvature (Source: Extraction from QGIS)

From Figure 9, we can see that most of the landslide lies in the region having positive profile curvature value which indicated the surface is upwardly concave at the cell. So, we can assume that, such upwardly concave surfaces are susceptible to landslides. Similarly, from Figure 10 we can see that most of the landslide lies in 
the region having positive tangential curvature value which indicated the surface is sideward concave at the cell[7]. So, we can assume that, such sideward concave surfaces are susceptible to landslides.

\subsection{Hydrological Analysis}

Hydrological Analysis is done to extract channel network and delineate watershed. As water is the major reason for most of the disaster, so hydrological analysis is very important in understanding the landslide susceptibility and its spatial distribution.

At first, flow accumulation raster is created where every cell represents the number of cells from which it collects water. And if we join the cells which exceed the threshold value, it will create a river network. Similarly, watershed is created by joining the raster cells from which water flows to create point. So, in this way channel network and drainage basins can be created.

Each segment of a stream or river within a river network is treated as a node in a tree, with the next segment downstream as its parent. When two first-order streams come together, they form a second-order stream. When two second-order streams come together, they form a third-order stream and so on. Thus, in Strahler's ordering the main channel is not determined; instead the ordering is based on the hierarchy of tributaries. Similarly, a drainage basin is an area where precipitation is collected and drains off to a common drain such as river, bay or other types of water body. The region comprises of perennial rivers (Kali Gandaki, Myagdi) and due to the hilly terrain there are river which are active in monsoon season and are responsible for huge sediment transport to basins at lower elevation. And hence give rise to many shallow types of landslide in this region. The landslide distribution from the main channel was analyzed by using Buffer tool. The result can be summarized as shown in Table 7 .

Table 7: Landslide Distribution Vs River Channel Buffer Zone (Source: Extraction from QGIS)

\begin{tabular}{|c|l|c|}
\hline $\begin{array}{c}\text { Buffer } \\
\text { Zone }\end{array}$ & Landslide_id & $\begin{array}{c}\text { No. of } \\
\text { Landslides }\end{array}$ \\
\hline 20 feet & $\begin{array}{l}2,4,19,33,34,36,37,38, \\
44,48,60\end{array}$ & 11 \\
\hline 40 feet & & \\
\hline 60 feet & 50 & 1 \\
\hline 80 feet & 63 & 1 \\
\hline
\end{tabular}

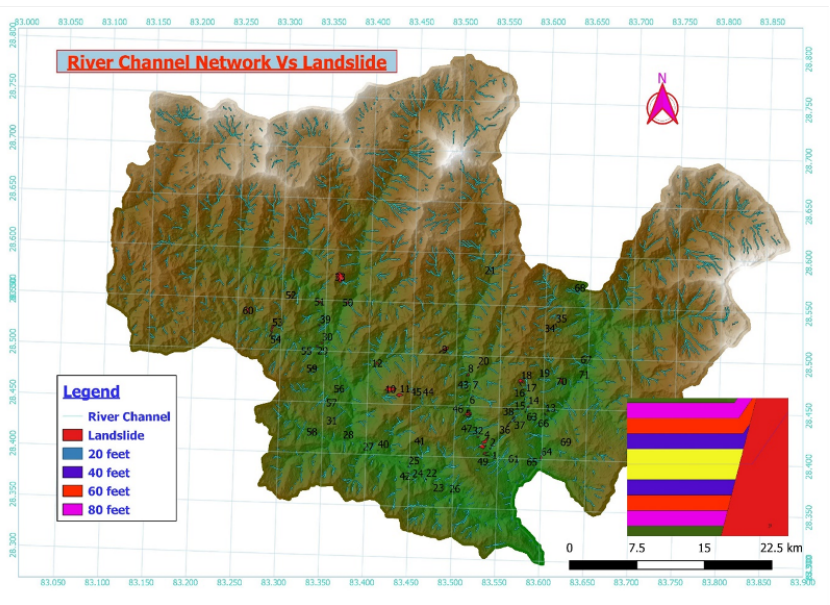

Figure 11: Spatial distribution of landslide Vs River Network with different buffer zones(Source: Extraction from QGIS)

\subsection{Landslide and Road Development}

Some vector analysis tools were used to better understand the distribution pattern of landslides and to clarify if the cause was actually artificial. Here different buffer zones around the road network were created to identify the landslide within its vicinity. Since the rural road construction is being done by using heavy machinery and without prior knowledge about the geology and meteorological study of the place, landslides are the consequence of this reckless acts. The result of vector analysis can be summarized in Table 8 .

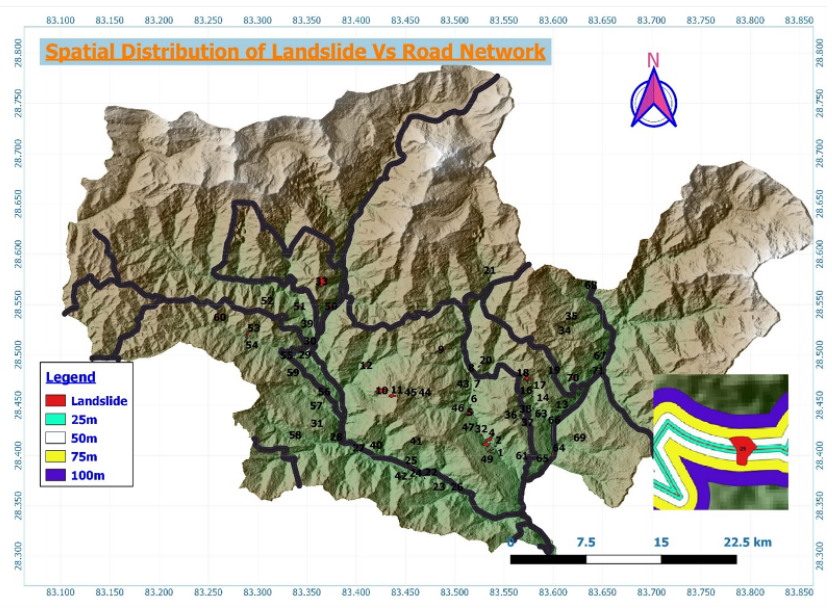

Figure 12: Spatial Distribution of landslide vs Road network with different buffered zones (Source: Extraction from QGIS) 
Table 8: Landslide Distribution Vs Road Network Buffer Zone (Source: Extraction from QGIS)

\begin{tabular}{|c|c|c|}
\hline $\begin{array}{c}\text { Buffer } \\
\text { Zone }\end{array}$ & Landslide_id & $\begin{array}{c}\text { No. of } \\
\text { Landslides }\end{array}$ \\
\hline 25 meter & $26,27,29,30,55,56$ & 6 \\
\hline 50 meter & 50 & 1 \\
\hline 75 meter & $40,25,64,39$ & 4 \\
\hline 100 meter & 7 & 7 \\
\hline
\end{tabular}

\subsection{Limitation}

Even though, all the above-mentioned analysis processes in methodology section requires less time and resources than field-based survey, it still does depend on some ground verification to make sure that the result of the assessment is authentic and reliable. So, some tangible information related to the district may add more authenticity and make this report more holistic and accurate. Since other tangible information related to the district was not available at this moment, this assessment was generally carried out based on the satellite images and DEM file and other relevant information found in different articles.

\section{Conclusion}

This assessment is generally based on the remote sensing data and the information which is generated is simply by using QGIS software. It can be considered as a preliminary study of landslide in Myagdi district. Although the study may seem informal as only some shape files, raster data and satellite image were under scrutiny to get information related to the landslide, this approach can be considered a powerful and effective tool for initial study landslide. This assessment thus highlights the key terrain, hydrological and anthropogenic parameters and their relationship with landslide in Myagdi district. The results of this study can be used for sustainable development planning and help in building efficient preparedness and mitigation measures to reduce the effects of landslide in this region.

From the terrain analysis we can notice that the landslide prone region lies in upper climate zones. Also, the windward side of hills receive more rainfall and are rich in vegetation, the landslides in this region are generally monsoon driven. If we study the leeward side which have comparatively less rainfall, dry landslides are common in this region and are activated due to various weathering actions.
Since the slope has direct correlation with water as water always flows downward, we can see from this study that the number of landslides is maximum in region where slope varies from 15 to 60 degrees. Similarly, if we consider the aspect which determines in which direction the land is facing, we can see that the region from North East to South West has higher susceptibility to landslide. And if we consider the profile curvature, we can notice that most of the landslide lies in the region having positive profile curvature value which indicates that the surface is upwardly concave. In case of tangential curvature, we can see that maximum number of landslides lies in the region having positive tangential curvature, which indicates sideward concave surface. Hydrological analysis result shows that there is maximum landslide in twenty feet buffer region from river channel. Also, we can see that the reckless road development without prior technical study can trigger landslide.

\section{References}

[1] J. F. Dewey, S. Cande, and W. C. Pitman, "Tectonic evolution of the India/Eurasia Collision Zone," Eclogae Geol. Helv., vol. 82, no. 3, pp. 717-734, 1989.

[2] J. Novotný, "Varnes Landslide Classification (1978)," Charles Univ. Prague, Fac. Sci. Czech Repub., no. November, p. 25 p. URL http://www.geology.cz/projekt681900/vyuk, 2013.

[3] F. Guzzetti, A. Carrara, M. Cardinali, and P. Reichenbach, "Landslide hazard evaluation: A review of current techniques and their application in a multi-scale study, Central Italy," Geomorphology, vol. 31, no. 1-4, pp. 181-216, 1999, doi: 10.1016/S0169-555X(99)00078-1.

[4] NDRRMA, "FY 2019 National Disaster Risk Reduction and Management Program , CA By Implementing Agency , By Expense Class Appropriations (RA 11260) Available Balance SARO for Approval OP Approved for SARO Issuance For OP Approval $1 /$ Details in ANNEX A,” vol. 2020, no. 1, pp. 1-17, 2020.

[5] G. A. Fenton, A. McLean, F. Nadim, and D. V. Griffiths, "Landslide hazard assessment using digital elevation models," Can. Geotech. J., vol. 50, no. 6, pp. 620-631, 2013, doi: 10.1139/cgj-2011-0342.

[6] P. Krebs, M. Stocker, G. B. Pezzatti, and M. Conedera, "An alternative approach to transverse and profile terrain curvature," Int. J. Geogr. Inf. Sci., vol. 29, no. 4, pp. 643-666, 2015, doi: 10.1080/13658816.2014.995102.

[7] A. Buckley, "Understanding curvature rasters," 2010. 